\title{
Lazaroa
}

ISSN-e 1988-3307

\section{Contribution to the phytosociological knowledge of rocky coastline of Corsica: description of five new plant associations}

\author{
Frédéric Bioret ${ }^{1}$, Pauline Delbosc ${ }^{1,2} \&$ Christophe Panaïotis $^{2}$
}

Received: 31 January 2016 / Accepted: 30 November 2016

Summary. In this article the authors study a few Corsican rocky coasts plant communities, within the framework of the development of the Prodrome vegetation of Corsica. This work is based on the analysis of 51 unpublished phytosociological relevés and their comparison with previous historical data. Five new plant associations and subassociations belonging to Saginetea maritimae (Catapodio marini-Hymenolobetum revelierii and Catapodio marini-Centaurietum tenuiflori), Crithmo maritimi-Limonietea (Loto cytisoidis-Juncetum acuti), Artemisietea vulgaris (Loto cytisoidis-Dactylidetum hispanicae crithmetosum maritime) and Helichryso italici-Crucianelletea maritimae (Helichryso italici-Thymelaeetum tartonrairae) are described on the coastal cliffs of Corsica. Their synecological and synfloristic characteristics are presented together to other environmental features.

Keywords: Corsica; seashore; halophilous vegetation; Saginetea maritimae; Crithmo maritimi-Limonietea; Artemisietea vulgaris; Helichryso italici-Crucianelletea maritimae.

\section{[es] Contribución al conocimiento fitosociológico de la vegetación de acantilados costeros de Córcega: descripción de cinco asociaciones nuevas}

Resumen. Las comunidades vegetales de los acantilados de Córcega han sido estudiadas en el marco del desarrollo del Pródromo de la vegetación de la isla de Córcega. Este trabajo presenta 51 inventarios fitosociológicos inéditos que han sido comparados con los datos históricos. Se describen como nuevas cinco asociaciones y subasociaciones de Saginetea maritimae (Catapodio marini-Hymenolobetum revelierii and Catapodio marini-Centaurietum tenuiflori), Crithmo maritimi-Limonietea (Loto cytisoidis-Juncetum acuti), Artemisietea vulgaris (Loto cytisoidis-Dactylidetum hispanicae crithmetosum maritime) and Helichryso italici-Crucianelletea maritimae (Helichryso italici-Thymelaeetum tartonrairae) para los acantilados de la costa de Córcega. Se presentan sus características florísticas y sinecológicas junto a otras más de tipo medioambiental.

Palabras clave: Córcega; comunidades vegetales costeras; vegetación halófila; Saginetea maritimae; Crithmo maritimi-Limonietea; Artemisietea vulgaris; Helichryso italici-Crucianelletea maritimae.

\section{Introduction}

Within the framework of the development of vegetation prodrome of Corsica coordinated by the national botanical conservatory of Corsica, several phytosociological synthesis and further work on new or relict vegetation reflecting the richness and originality of the corsican vegetations were undertaken.
Recent surveys have allowed us to study several original plant communities of the rocky coast of Corsica (Cap Corse region, Crovani, Revellata, Fango, Bonifacio). This work completes phytosociological works on corsican coastal vegetation (Paradis \& Piazza 1991; Géhu \& Biondi, 1994; Paradis \& al. 1999; Paradis \& al. 2010; Paradis \& al., 2013; Paradis \& al., 2014). Two therophytic plant

EA 2219 Géoarchitecture, Université de Bretagne Occidentale, UFR Sciences et Techniques, CS 93867, 29238 Brest Cedex 3. France. Email : frederic.bioret@univ-brest.fr

2 Conservatoire Botanique National de Corse, Office de l'Environnement de la Corse, av. Jean Nicoli, 20250 Corte. France. 
communities, two halophilous perennial grass, one chasmo-halophilous vegetation and one chamephytic low scrubland are described.

\section{Materials and Methods}

From 2009 to 2013, 52 phytosociological relevés were realized on physiognomic, floristic and ecological homogeneous areas, according to the sigmatist phytosociological method (Guinochet, 1973; Géhu, 1986; Géhu \& Rivas-Martínez, 1981). Taxonomic nomenclature follows Flora Corsica (Jeanmonod \& Gamisans, 2007).

\section{Results and Discussion}

\section{Catapodio marini-Hymenolobetum revelierei} ass. nova hoc loco

(holotypus: Table 1, rel. 6).

Symphysiognomy. This therophytic vegetation looks very open, it is not higher than 10 $\mathrm{cm}$ being physiognomically dominated by Hymenolobus procumbens (L.) Nutt. subsp. revelieri (Jord.) Greuter \& Burdet. Its phenological optimum corresponds to that of Hymenolobus procumbens subsp. revelieri that quickly dries up from May.

Synfloristic characteristics. This community is characterized by a floristic combination of several vernal therophytes: Hymenolobus procumbens subsp. revelieri, Catapodium marinum (L.) C.E. Hubb. and Parapholis incurva (L.) CE Hubb. Limonium contortirameum Erben and Frankenia laevis L. Other species of Crithmo maritimi-Limonietea Braun-Blanq. in Braun-Blanq., Roussine \& Nègre 1952 are regularly present.

Synecology. This plant community develops on wind and salt spray exposed coastal cliffs. It grows on silty clay compacted depositions which regularly received humidity from seawater spraying. This freshness is also maintained by the shady situation of north or northeast facing cliffs, by the presence of overhanging rocks (Giraglia islet) and by the proximity to the sea (altitude ranging between 5 and 20 m). On the cliffs of Barcaggio, Hymenolobus procumbens subsp. revelieri vegetation preferentially develops under the protection of Juniperus phoenicea L. subsp. turbinata (Guss.) Nyman that provides it an almost permanent shade, preventing from a too rapid drying up in the spring.

This plant community is close to Sileno sedoidis-Hymenolobetum revelierii Brullo \& Giusso del Galdo 2003 that develops in very similar ecological conditions, on the Italian coast of Taranto region (Brullo \& Giusso del Galdo, 2003). Floristically, it differs by the presence of Catapodium marinum replacing Catapodium balearicum (Willk.) H. Scholtz (in the Italian syntaxon) and by the absence of Silene sedoides Poir.

Syndynamic, catenal position. Catapodio marini-Hymenolobetum revelierii develops at the upper contact of perennial hyperhalophilous vegetation of Crithmo maritimi-Limonietea, represented in the Cap Corse by Crithmo maritimiLimonietum contortiramei Géhu \& Biondi 1994 typicum and Crithmo maritimi-Limonietum contortiramei frankenietosum laevis Géhu \& Biondi 1994, and at the lower contact of the Juniperus phoenicea coastal scrubland belonging the Juniperion turbinatae Rivas-Mart. 1975. Due to stational ecological constraints, this association is stable from a dynamic point of view.

Synchorology. This association presents a very limited distribution, as it is observed on a few rocky sites of the northern end of the Cap Corse. Further surveys would complete the knowledge of its chorology, especially on the Finocchiarola islets where Hymenolobus revelieri was identified (Jeanmonod \& Gamisans, 2007; Paradis \& Piazza, 2002; Rivière \& al., 2012), and on two islands of the Marseille archipelagoes (Pomègues (Frioul) and Riou), where one of us (FB) had the opportunity to observe two stations Hymenolobus procumbens subsp. revelieri in 2004.

Syntaxonomy. This plant community may be linked to Saginetalia maritimae and to Saginion maritimae because it develops on sandy cliffs shallow soils in halophilous conditions. 
Table 1. Catapodio marini-Hymenolobetum revelierii ass. nova (Saginion maritimae, Saginetalia maritimae, Saginetea maritimae)

\begin{tabular}{|c|c|c|c|c|c|c|c|c|c|c|}
\hline Area $\left(\mathrm{m}^{2}\right)$ & 0.25 & 1.5 & 0.25 & 0.5 & 0.25 & 0.75 & 0.25 & 1.5 & 1.5 & \\
\hline Cover (\%) & 20 & 25 & 40 & 50 & 70 & 50 & 20 & 50 & 80 & \\
\hline N. species & 4 & 5 & 4 & 6 & 8 & 7 & 7 & 11 & 6 & \\
\hline Mean N. species & . & . & . & . & . & . & . & . & . & 6.4 \\
\hline Relevé N. & 1 & 2 & 3 & 4 & 5 & 6 & 7 & 8 & 9 & 10 \\
\hline \multicolumn{11}{|l|}{ Characteristics: } \\
\hline Hymenolobus procumbens subsp. revelieri & 2 & 2 & 1 & 3 & 2 & 3 & 1 & 3 & + & $\mathrm{V}$ \\
\hline Catapodium marinum & + & . & 2 & 1 & 3 & 2 & . & 1 & + & IV \\
\hline Parapholis incurva & 1 & + & 1 & 1 & + & 1 & . & + & . & IV \\
\hline Valantia muralis & . & . & . & . & . & . & . & + & . & I \\
\hline Cerastium semidecandrum & . & . & . & . & . & . & . & + & . & I \\
\hline Sagina maritima & . & . & . & . & . & . & 2 & . & . & I \\
\hline Senecio transiens & . & . & . & . & . & . & 1 & . & . & I \\
\hline \multicolumn{11}{|l|}{ Crithmo-Limonietea characteristics: } \\
\hline Limonium articulatum & . & 1 & . & 1 & 1 & + & 1 & 1 & 3 & IV \\
\hline Frankenia laevis subsp. laevis & 1 & 1 & . & . & . & . & + & 1 & 4 & III \\
\hline Crithmuт maritimum & . & . & . & . & + & + & . & . & + & II \\
\hline Daucus carota subsp. hispanicus & . & . & . & . & . & . & + & + & . & I \\
\hline Halimione portulacoides & . & + & . & . & . & . & . & . & . & I \\
\hline \multicolumn{11}{|l|}{ Other species: } \\
\hline Reichardia picroides & . & . & + & . & 2 & + & - & + & . & III \\
\hline Plantago coronopus & . & . & & + & 1 & + & . & 2 & . & III \\
\hline Helichrysum italicum subsp. italicum & . & . & . & + & . & . & . & . & 1 & II \\
\hline \multicolumn{11}{|c|}{$\begin{array}{l}\text { Other species: Dianthus sylvestris subsp. longicaulis var. godronius } 2 \text { in 7; Euphorbia pithyusa }+ \text { in } 7 \text {; Stellaria } \\
\text { pallida }+ \text { in 9. All species I in } 10 .\end{array}$} \\
\hline Localities: 1, 2: La Giraglia (September 20 & & & & & & & & & & \\
\hline
\end{tabular}

Catapodio marini-Centaurietum tenuiflori ass. nova hoc loco (holotypus: Table 2, rel. 1).

Symphysiognomy. This plant community is a therophytic short grassland, which height not exceed $10 \mathrm{~cm}$, with low covers (not more than $50 \%$ ). They are dominated by Centaurium tenuiflorum (Hoffmanns. \& Link) Fritsch and Catapodium marinum (L.) C.E. Hubb.

Synecology. This heliophilous grassland develops on edges of coastal rocky cliffs highly exposed to salt spray, at an altitude ranging between 10 and $30 \mathrm{~m}$, on crystalline substrates (Fango valley) or on schist substrates (Cap Corse). The substrate is an acidicline to acidiphile superficial lithosol, sandy gravel with a silty-sandy interstitial matrix.

Synfloristic characteristics. The species composition allows to differentiate this grassland from other syntaxa of the Saginetea maritimae present in Corsica (Géhu \& Biondi,
1994; Paradis \& al., 2014). It is characterized by a floristic combination of therophytic species regularly associated: Centaurium tenuiflorum, Catapodium marinum, Filago minima (Sm.) Pers. and Trifolium scabrum L. The presence of Helichrysum italicum (Roth) G. Don. subsp. italicum indicates the contact with short coastal shrublands.

Syndynamic, catenal position. This plant community develops at the upper contact of Crithmo maritimi-Limonietea Br.-Bl. in Br.-Bl., Roussine \& Negro 1952, and at the lower contact of Loto cytisoidis-Dactylidetum hispanicae Biondi, Filigheddu \& Farris 2001, Euphorbio pithyusae-Helichrysetum italici Paradis \& Piazza, 1998 or Thymelaea tartonraira and Helichrysum italicum subsp. italicum community.

Synchorology. This association is rare on the coast of Corsica, where it has been observed in only three stations: north of Cap Corse, between Macinaggio and Tamarone (Rogliano) and north of Fango delta (Galéria). 
Table 2. Catapodio marini-Centaurietum tenuiflori ass. nova (Saginion maritimae, Saginetalia maritimae, Saginetea maritimae)

\begin{tabular}{|c|c|c|c|c|c|c|c|c|c|}
\hline Area $\left(\mathrm{m}^{2}\right)$ & 2 & 0.5 & 3 & 1 & 0.3 & 0.25 & 0.25 & 0.25 & \\
\hline Cover $(\%)$ & 20 & 40 & 20 & 20 & 60 & 40 & 40 & 30 & \\
\hline N. species & 6 & 4 & 6 & 7 & 9 & 6 & 6 & 4 & \\
\hline Mean N. species & & & & & & & & & 6 \\
\hline Relevé N. & 1 & 2 & 3 & 4 & 5 & 6 & 7 & 8 & 9 \\
\hline \multicolumn{10}{|l|}{ Characteristics: } \\
\hline Centaurium tenuiflorum & 2 & 1 & 3 & 1 & 2 & 1 & 2 & 2 & V \\
\hline Catapodium marinum & 1 & 3 & 1 & 2 & + & + & 1 & 2 & V \\
\hline Filago minima & + & & + & 1 & . & . & . & . & III \\
\hline Silene gallica & + & + & + & . & . & . & . & . & III \\
\hline Parapholis incurva & . & . & . & . & . & 2 & 3 & . & II \\
\hline Trifolium scabrum & . & . & . & . & 3 & + & . & . & II \\
\hline Plantago coronopus & . & . & . & 1 & + & . & . & . & II \\
\hline Centaurium maritimum & . & . & . & + & . & . & . & . & II \\
\hline \multicolumn{10}{|l|}{ Other species: } \\
\hline Dactylis glomerata subsp. hispanica & + & 2 & + & . & . & . & 2 & . & III \\
\hline Linum trigynum & + & . & . & + & + & . & + & . & III \\
\hline Sonchus tenerrimus & . & . & . & & + & . & . & + & II \\
\hline Lotus cytisoides & . & . & . & . & + & . & . & + & II \\
\hline Plantago bellardii subsp. bellardii & . & . & . & + & . & + & . & . & II \\
\hline
\end{tabular}

\section{Helichryso italici-Thymelaeetum tartonrairae} Bioret, Delbosc, Panaïotis \& Paradis ass. nova hoc. loco (holotypus: Table 3, rel. 1).

Symphysiognomy. This chamephytic plant community corresponds to a short scrubland dominated by Thymelaea tartonraira L. All. subsp. tartonraira and Helichrysum italicum (Roth) G. Don. subsp. italicum. The vegetation cover is more or less important, according to the topographic conditions and the nature of the substrate.

Synfloristic characteristics. This community is characterized by a regularly floristic combination of the two chamaephytes that named the association together to Lotus cytisoides L. subsp.cytisoides, Reichardia picroides (L.) Roth, Dactylis glomerata L. subsp. hispanica and Daucus carota L. subsp. hispanicus (Gouan) Thell.

Synecology. This shrubland occupies the upper part of the coastal cliffs, in semi-sheltered conditions, between 15 and $70 \mathrm{~m}$ in the Cap Corse and at much lower altitudes in the Fango region. It develops on shallow lithosoils, poor in nutrients, on a various geological substrates: peridotite (lustrous schists) in the Cap Corse, rhyolite in the Scandola Nature Reserve or granodiorite in the Fango.

Because of its synecological characteristics, this group shows similarities with the Thymelaeo hirsutae-Helichrysetum italici R. Molinier 1959 but differs from it because of the presence of Thymelaea tartonraira subsp. tartonraira and the absence of Thymelaea hirsuta L. From an ecological point of view, it develops on more basic geological substrates, whereas Thymelaeo hirsutae-Helichrysetum italici seems associated to more acid crystalline substrates.

Recently, in an unpublished report requested by the national botanical Conservatory of Corsica (Paradis, 2010), the author proposed the name Thymelaeo tartonrairae-Helichrysetum italici which is not valid (art. 2, Weber \& al., 2000). Thymelaea tartonraira subsp. tartonraira appears more abundant than Helichrysum italicum subsp. italicum being the structural element of such scrubland.

This plant community presents three ecological variations considered as distinct subassociations:

typicum.

schoenetosum nigricantis subass. nova hoc. loco (holotypus: Table 3, rel.9). Mesohygrophilous 
variation on steepy north facing slopes. Paradis (2010) considered it as a facies at Schoenus nigricans.

dianthetosum siculi subass. nova hoc. loco (holotypus: Table 3, rel. 20). Halophilous variation on the edges of the upper part of cliffs, exposed to salt spray, on relatively gentle slopes, differentiated by Dianthus sylvestris subsp. siculus. Géhu \& Biondi (1994, Table 59, p. 108) considered it as a Dianthus sylvestris and Thymelaea tartonraira community).

Syndynamic, catenal position. The Helichryso italici-Thymelaeetum tartonrairae develops at the upper contact to halo-anemophilous grassland of Loto cytisoidis-Dactylidetum hispanicae Biondi, Filigheddu \& Farris 2001 and at the lower contact of Juniperus phoenicea L. subsp.turbinata Guss. Nyman scrubland (Oleo sylvestrisJuniperetum turbinatae Arrigoni, Bruno, De Marco \& Veri 1985 corr. Biondi \& Mossa 1992). The presence of several species of nanophanerophytes (Erica arborea L., Arbutus unedo L., Myrtus communis L.) characterize the contact with the Juniperion turbinatae Rivas-Mart. 1975.

Synchorology. This association remains localized in a few points of the rocky coast of Corsica: north of Cap Corse (near Barcaggio), southwest of the lighthouse near the Punta di Corno di Becco (Paradis, 2010) and north of Nonza. In 2013, it has been identified above the stream Grotta alle Piane, and on the northwest slope near the Monte Grande, close to the lighthouse. We discovered two additional stations in the Scandola Nature Reserve and on the rocky coastline north of the Fango delta (Galéria). Table 3 includes 10 relevés recorded, 6 relevés of G. Paradis (2010), and 6 of Géhu \& Biondi (1994).

Heritage Value. This plant association is closely linked to the presence of Thymelaea tartonraira subsp. tartonraira, protected species at the national level and fairly rare in Corsica. Too frequent fires represent the main threat for this high valuable syntaxon.

Syntaxonomy. Biondi \& al. (2001) include the Rosmarino officinalis-Thymelaeetum tartonrairae (whose physiognomy and floristic composition are very similar to this new association) in Rosmarinetea officinalis, Rosmarinetalia officinalis and Cisto eriocephaliEricion multiflorae. Rosmarinetea officinalis corresponds to shortcalcicolous westMediterraneanscrubs (matorral, garrigue, tomillar). Howeverwe think Helichrysoitalici-Thymelaeetum tartonrairae could be better integrated in Helichrysetalia italici Géhu \& Biondi 1994, Euphorbion pithyusae Géhu \& Biondi 1994 that correspond to chamephytic vegetation dominated by Helichrysum italicum on rocky coasts. 


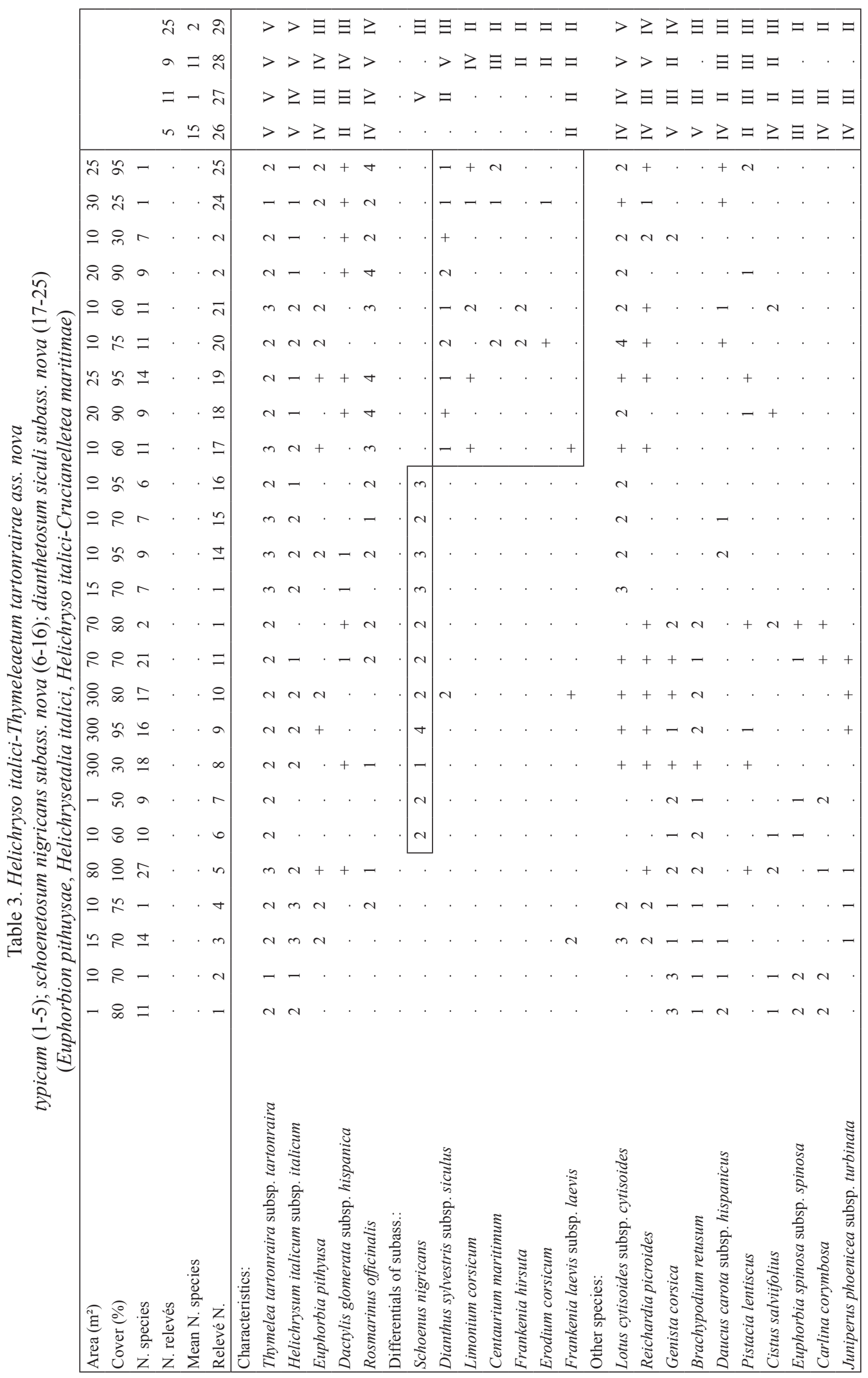




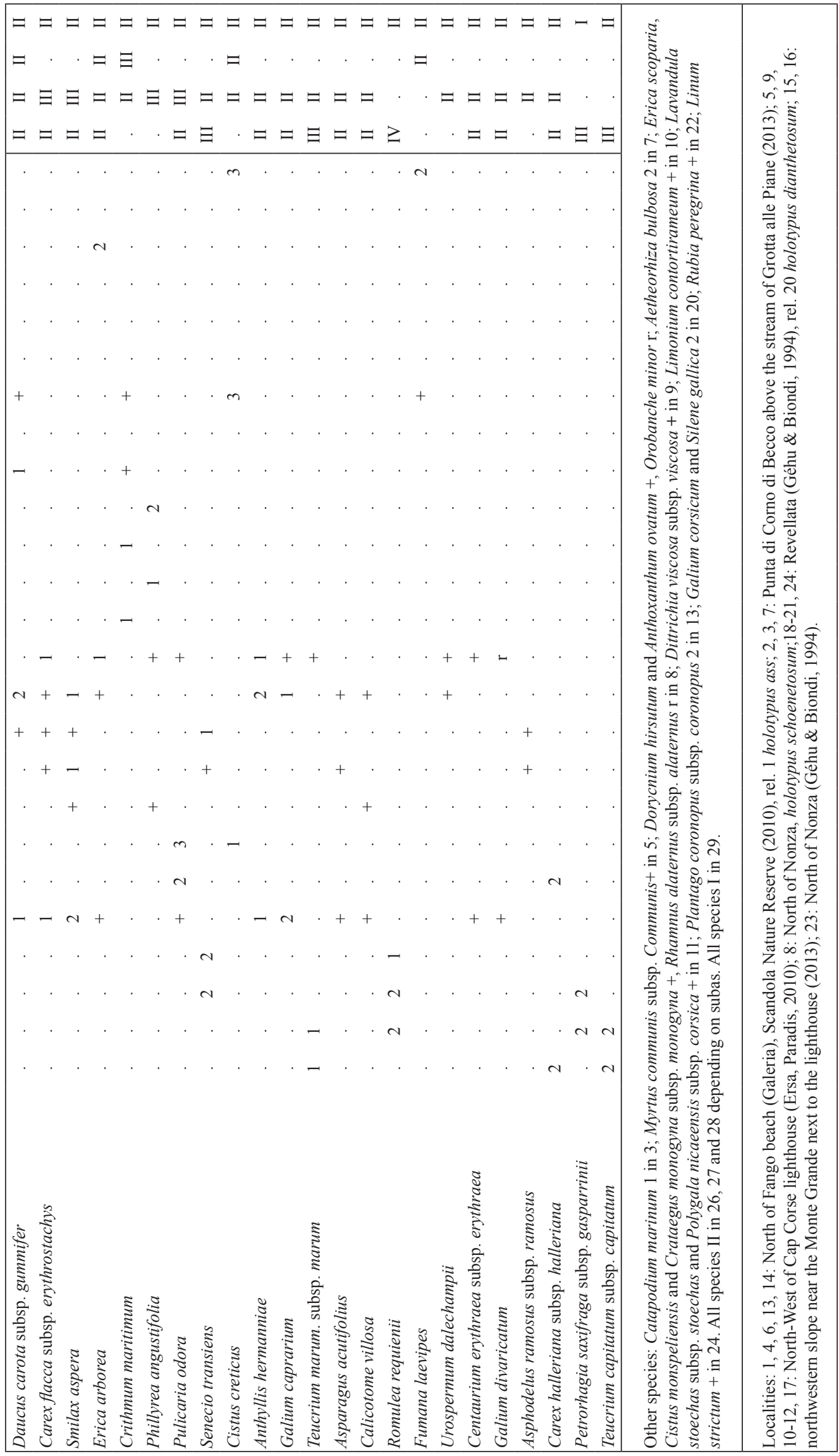


Loto cytisoidis-Juncetum acuti ass. nova hoc loco (holotypus: Table 4, rel. 7).

Symphysiognomy. This herbaceous plant community represents the chasmo-halophilous vegetation of fissures in wet coastal rocks. It is characterized by the dense clumps of Juncus acutus L. subsp. acutus, which can reach one meter of height.

Synecology. This group colonizes cracks of rocks or the lower parts of the cliffs, close to the sea, exposed to frequent alt spray and sea water projections and where rain water can accumulate. It usually develops on hyperacid crystalline substrates such as porphyritic monzogranite or at medium grain and granodiorite at medium grain (Rossi \& Rouire, 1980a, b).

Synfloristic characteristics. The floristic composition is characterized by a combi- nation associating regularly Juncus acutus L. subsp. acutus and Lotus cytisoides L. subsp. cytisoides, accompanied by Crithmum maritimum L.

Syndynamic, catenal position. Considering the very constraining environmental conditions, it should be considered as permanent vegetation. It develops at the upper contact of chasmo-halophilous vegetations of Crithmo maritimi-Staticetea Br.-B1. in Br.-B1., Roussine \& Nègre 1952 and is at the lower contact of Euphorbio pithyusae-Helichrysetum italici Paradis \& Piazza 1998.

Synchorologie. This plant community is present in most of the Corsican coast from the west coast (Crovani) to the southeast (Fautea). It can be considered as geosynvicariant of the atlantic Crithmo maritimi-Juncetum acuti Bioret 2008 present along the western coast of the Massif armoricain (Bretagne).

Table 4. Loto cytisoidis-Juncetum acuti ass. nova

(Crithmo-Limonion articulati, Crithmo-Limonietalia, Crithmo-Limonietea)

\begin{tabular}{|c|c|c|c|c|c|c|c|c|c|c|}
\hline Area $\left(\mathrm{m}^{2}\right)$ & 3 & 3 & 3 & 2 & 3 & 4 & 1 & 1 & 2 & \\
\hline Cover $(\%)$ & 80 & 100 & 90 & 100 & 75 & 100 & 95 & 80 & 90 & . \\
\hline N. species & 6 & 3 & 4 & 3 & 4 & 4 & 2 & 3 & 3 & . \\
\hline Mean number species & . & . & . & . & . & . & . & . & . & 3.6 \\
\hline Relevé N. & 1 & 2 & 3 & 4 & 5 & 6 & 7 & 8 & 9 & 10 \\
\hline \multicolumn{11}{|l|}{ Characteristics: } \\
\hline Juncus acutus subsp. acutus & 5 & 5 & 5 & 3 & 4 & 5 & 4 & 3 & 5 & V \\
\hline Lotus cytisoides & 1 & 2 & 1 & 2 & . & 1 & 1 & 3 & 1 & V \\
\hline \multicolumn{11}{|l|}{ Differential sub-association: } \\
\hline Crithmum maritimum & 2 & 2 & 1 & 3 & 2 & . & . & . & . & IV \\
\hline \multicolumn{11}{|l|}{ Other species: } \\
\hline Dactylis glomerata subsp. hispanica & 1 & . & . & . & . & . & . & 1 & . & II \\
\hline \multicolumn{11}{|c|}{$\begin{array}{l}\text { Other species: Helichrysum italicum subp. italicum 2, Euphorbia pithyusa }+ \text { in } 1 \text {; Erodium corsicum }+ \\
\text { in } 3 ; \text { Sporobolus pungens } 1 \text {, Dittrichia viscosa subsp. viscosa }+ \text { in 5; Cynodon dactylon } 1 \text {, Convolvulus } \\
\text { arvensis } 2 \text { in 6; Phragmites australis }+ \text { in } 9 \text {. All species II in } 10 .\end{array}$} \\
\hline
\end{tabular}

Loto cytisoidis-Dactylidetum hispanicae Biondi, Filigheddu \& Farris 2001 (Table 5)

Symphysiognomy. This dense maritime grassland is dominated by Crithmum maritimum, Daucus carota subsp. hispanicus,
Lotus cytisoides and Dactylis glomerata subsp. hispanica.

Synecology. It is present on steepy slopes of hyperventilate cliffs, exposed to salt spray, in fresh conditions, always corresponding to the north or northeast facing condition, often 
reinforced by the geomorphological configuration of the coastline. The substrate corresponds to less stable clay-stony shallow soils, sometimes enriched with gravels.

Synfloristic characteristics. This grassland is dominated by Daucus carota subsp. hispanicus, Lotus cytisoides and Dactylis glomerata subsp. hispanica. Our relevés showed in Table 5 correspond to a halophilous variation, differentiated by Crithmum maritimum, which can be considered an original sub-association: crithmetosum maritimi subass. nov. hoc loco (holotypus: Table 5 , rel. 7).

Table 6 shows the comparison of summary tables of salt-tolerant grasslands with Daucus carota subsp. hispanicus. Loto cytisoidisDactyletum hispanicae Biondi, Filigheddu \& Farris 2001 crithmetosum maritimi differs from Dauco hispanici-Asteriscetum maritimus Wojterski 1988 crithmetosum maritimi, by the absence of aerohaline species such as Plantago macrorhiza, Sporobolus arenarius or Parapholis incurvus and the presence of more salt-tolerant species such as Euphorbia pithuysa or Frankenia laevis and nitrophilous ones (Carlina corymbosa, Cynodon dactylon, Gaudinia fragilis).
In Algeria, a halophilous vegetation of rock crevices in calcareous sandstone with Asteriscus maritimus and Daucus carota subsp. hispanicus was analysed by Géhu \& al. (1992) as being the Dauco hispanici-Asteriscetum maritimus Wojterski 1988. These authors described a subassociation crithmetosum maritimi of rocky cracks in the most salt sprayed sites. This syntaxon recorded on the Mediterranean southern shores, can be considered as geosynvicariant of the Loto cytisoidis-Dactyletum hispanicae Biondi, Filigheddu \& Farris 2001 crithmetosum maritimi in Corsica. Furthermore, from a synecological and phytogeographical perspective, this grasslands presents similarities with the Dactylo oceanicaeDaucetum gummiferi Géhu 2008 on the Atlantic cliffs of the Massif armoricain (Bretagne).

Syndynamic, catenal position. This grassland is a permanent vegetation which develops at the lateral contact of the Euphorbio pithyusaeHelichrysetum italici Paradis \& Piazza 1998.

Synchorology. This syntaxon observed in Corsica on the cliffs of Scandola Nature Reserve (islet of Gargalu) and on the cliffs of Cap Corse is probably present in others localities. 
Table 5. Loto cytisoidis-Dactyletum hispanicae Biondi, Filigheddu \& Farris 2001

crithmetosum maritimae subass. nova (1-7)

(Reichardio maritimae-Dactylion hispanicae, Brachypodio

ramosi-Dactyletalia hispanicae, Artemisietea vulgaris)

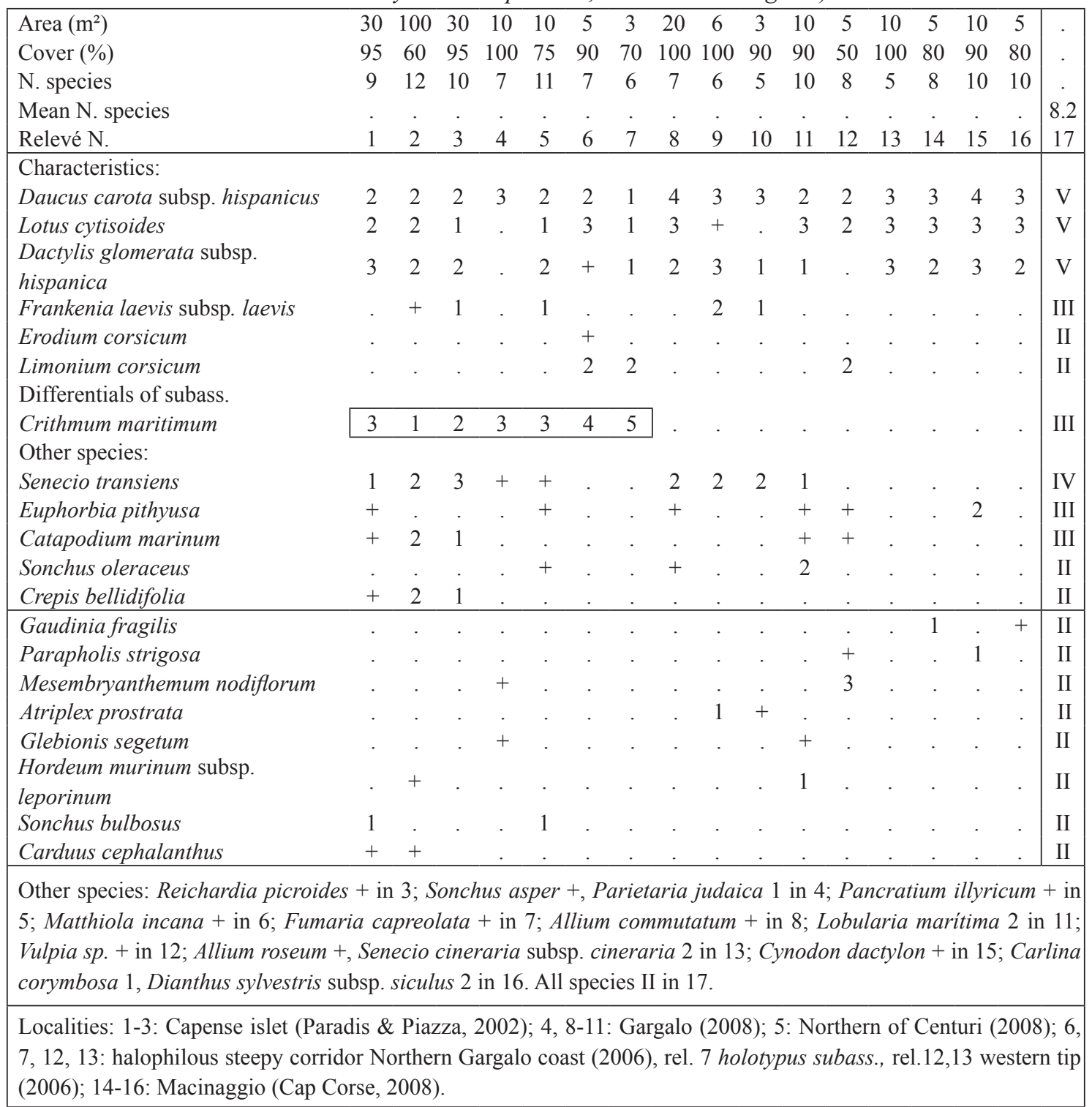

\section{Dauco hispanici-Asteriscetum maritimi} Wojterski 1988 (Table 7).

Symphysiognomy. This calcicolous halophilous grassland is dominated by Asteriscus maritimus and Daucus carota subsp. hispanicus.

Synecology. This salt-tolerant grassland develops in crevices and rocky edges of limestone cliffs of Bonifacio (lower and middle Miocene: bioclastic limestone (Rossi \& Rouire, 1980a, b) with a sandy-silty interstitial matrix. It is present in micro-valleys facing the sea, hyperventilated and regularly exposed to salt spray. It was also observed in a situation of rocky ledge at the cliff top.

Synfloristic characteristics. The floristic composition is characterized by Pallenis maritimus and Daucus carota subsp. hispanicus, associated with hyperhalophilous species: Limonium obtusifolium, Lotus cytisoides and Sporobolus pungens.

Due to its synfloristical and synecological characteristics, this grassland may correspond to the Dauco hispanici-Asteriscetum maritimi Wojterski 1988 (Wojterski, 1988), mentioned on the coast of Kabylia and the 
Alger region (Géhu \& al., 1992; Khelifi \& al., 2008). The ecological singularity of the relevé 3 realized on rocky ledge at the top of the cliff hyperexposed at sea spray, represents a halophilous variation characterized by the abundance of Crithmum maritimum: this relevé 3 correspond to the Dauco hispanici-Asteriscetum maritimi Wojterski 1988 crithmetosum maritimi Géhu, Kaabeche \& Gharzouli 1992.

Table 6. Synoptic table of Daucus carota subsp. hispanicus halophilous communities.

Loto cytisoidis-Dactyletum hispanicae Biondi et al. 2001, pag. 53 (1)

Loto cytisoidis-Dactyletum hispanicae, hispanicae crithmetosum maritimae.

Crithmetosum maritimae table 5 (2)

Dauco hispanici-Astericetum maritimi Wojterski 1988, pag. 320 (3)

(Reichardio maritimae-Dactylion hispanicae, Brachypodio ramosi-Dactyletalia hispanicae, Artemisietea vulgaris)

\begin{tabular}{|c|c|c|c|}
\hline N. relevés & 8 & 16 & 7 \\
\hline Mean N. species & 14.3 & 8.2 & 5.7 \\
\hline Relevé N. / Syntaxon & 1 & 2 & 3 \\
\hline Daucus carota subsp. hispanicus & $\mathrm{V}$ & $\mathrm{V}$ & $\mathrm{V}$ \\
\hline Lotus cytisoides & V & V & IV \\
\hline Dactylis glomerata subsp. hispanica & V & $\mathrm{V}$ & III \\
\hline Catapodium marinum & . & III & II \\
\hline Crithmum maritimum & . & III & III \\
\hline Pallenis maritima & . & . & $\mathrm{V}$ \\
\hline \multicolumn{4}{|l|}{ Other species: } \\
\hline Euphorbia pithyusa & IV & III & . \\
\hline Frankenia laevis subsp. laevis & IV & III & . \\
\hline Carlina corymbosa & IV & II & . \\
\hline Cynodon dactylon & IV & II & . \\
\hline Gaudinia fragilis & IV & II & . \\
\hline Reichardia picroides & $\mathrm{V}$ & II & . \\
\hline Pancratium illyricum & II & II & . \\
\hline Crocus minimus & IV & . & . \\
\hline Helichrysum italicum subsp. mycrophyllum & IV & . & . \\
\hline Iris sisyrinchium & IV & . & . \\
\hline Limonium acutifolium & IV & . & . \\
\hline Lagurus ovatus & IV & . & . \\
\hline Avena fatua & III & . & . \\
\hline Beta vulgaris subsp. maritima & III & . & . \\
\hline Carex flacca subsp. serrulata & III & . & . \\
\hline Centaurium erythraea & III & . & . \\
\hline Convolvulus althaeoides & III & . & . \\
\hline Orobanche sp. & III & . & . \\
\hline Senecio transiens & . & IV & . \\
\hline Plantago macrorhiza & . & . & IV \\
\hline Hyoseris radiata & . & . & IIl \\
\hline Sporobolus arenarius & . & . & II \\
\hline Plantago crassifolia & . & . & II \\
\hline \multicolumn{4}{|c|}{$\begin{array}{l}\text { Plantago lanceolata subsp. sphaerostachya, Matthiola tricuspidata and Inula viscosa } \text { II in 1; Sonchus } \\
\text { bulbosus, Allium commutatum, Allium roseum, Atriplex prostrata, Carduus cephalanthus, Glebionis } \\
\text { segetum, Crepis bellidifolia, Dianthus sylvestris subsp. siculus, Erodium corsicum, Fumaria capreolata, } \\
\text { Hordeum murinum subsp. leporinum, Limonium corsicum, Lobularia maritima, Matthiola incana, } \\
\text { Mesembryanthemum nodiflorum, Parapholis strigosa, Parietaria judaica, Senecio cineraria, Sonchus } \\
\text { asper, Sonchus oleraceus and Vulpia sp. II in 2; Imperata cylindrica, Laurentia michelii, Linum strictum, } \\
\text { Parapholis incurvus, Schoenus nigricans, Sedum caeruleum II in } 3 \text {. }\end{array}$} \\
\hline
\end{tabular}


Syndynamic, catenal position. The Dauco hispanici-Asteriscetum maritimi is situated in the upper contact of Crithmo maritimiLimonietum obtusifolii Géhu \& al. 1987 and at the lower of Helichryso microphylliAstragaletum massiliensis Géhu \& al. 1987. When the substrate is more mineral, the Dauco hispanici-Asteriscetum maritimi develops at the lower contact of Helichryso microphylli-Asteriscetum maritimi (Gamisans 1990) Géhu \& Biondi, 1994.
Synchorology. In Corsica, this vegetation was observed on the limestone plateau of Bonifacio, more precisely in micro-valleys to the north and southeast, near Pertusato lighthouse. In the Mediterranean, this association is present in Algeria, on Numidia sandstone and at the west of Djijel coast, where it develops on red sandstone type calcareous substrates (Géhu \& al., 1992).

Table 7. Dauco hispanici-Astericetum maritimi Wojterski 1988 crithmetosum maritimae Géhu \& al. 1992 (Asteriscion maritimi, Crithmo-Limonietalia, Crithmo-Limonietea)

\begin{tabular}{|c|c|c|c|c|c|}
\hline Area $\left(m^{2}\right)$ & 3 & 10 & 10 & . & • \\
\hline Cover $(\%)$ & 60 & 70 & 100 & . & . \\
\hline N. species & 5 & 7 & 8 & . & . \\
\hline Mean N. species & . & . & . & . & 9.2 \\
\hline Relevé number & 1 & 2 & 3 & 4 & $5 *$ \\
\hline \multicolumn{6}{|l|}{ Characteristics: } \\
\hline Pallenis maritima & 2 & 3 & + & 3 & $\mathrm{~V}$ \\
\hline Daucus carota subsp. hispanicus & + & + & 2 & 3 & $\mathrm{~V}$ \\
\hline Lotus cytisoides & . & 2 & 3 & 2 & $\mathrm{~V}$ \\
\hline Helichrysum italicum subsp. microphyllum & 1 & + & . & 2 & III \\
\hline Dactylis glomerata & . & . & . & . & $\mathrm{V}$ \\
\hline Hyoseris radiata & . & . & . & . & $\mathrm{V}$ \\
\hline Reichardia picroides & . & . & . & . & IV \\
\hline Hedypnois cretica & . & . & . & . & III \\
\hline Convolvulus althaeoides & . & . & . & . & III \\
\hline Plantago serraria & . & . & . & . & III \\
\hline Sonchus oleraceus & . & . & . & . & III \\
\hline Lagurus ovatus & . & . & . & . & III \\
\hline Centaurea sphaerocephala & . & . & $\cdot$ & . & III \\
\hline \multicolumn{6}{|c|}{$\begin{array}{l}\text { Characteristics: Limonium obtusifolius } 2 \text {, Senecio leucanthemifolius }+ \text { in } 1 \text {; Lobularia maritima } 1 \text {, } \\
\text { Sporobolus pungens and Sonchus bulbosus }+ \text { in } 2 \text {; Crithmum maritimum } 3 \text {, Anthemis maritima and } \\
\text { Plantago coronopus } 1 \text {, Camphorosma monspeliaca and Allium commutatum }+ \text { in } 3 \text {; all species } 1 \text { in 4; } \\
\text { Ammophila arenaria, Rumex tingitanus, Silene glauca, Hypochoeris achyrophorus, Smilax aspera and } \\
\text { Avena sterilis II in } 5 .\end{array}$} \\
\hline \multicolumn{6}{|c|}{$\begin{array}{l}\text { Localities: 1, 3: Southwest Pertusato lighthouse; 2: Northwest Pertusato lighthouse (2013). (Asteric } \\
\text { refers to the original table by Wojterski, 1988). }\end{array}$} \\
\hline
\end{tabular}

\section{Conclusion}

This work allowed us to describe five new syntaxa of Saginetea maritimae, Crithmo maritimi-Limonietea and Helichryso italiciCrucianelletea maritimae Géhu, Rivas-Martínez \& Tüxen in Géhu 1975 and to identify a new syntaxon for Corsica, the Dauco hispaniciAsteriscetum maritimi. It completes the knowledge of the vegetation of the rocky coast of Corsica, and of Saginetea maritimae and Crithmo maritimi-Limonietea associations (de Foucault \& Bioret, 2010; Paradis, 2010; Paradis \& al., 2013; Paradis \& al., 2014). 
These coastal vegetation is scarce and do not appear directly threatened because of their particular ecological conditions. However, their limited geographical distribution provides them a consequent heritage value.
Following partially Bardat \& al. (2004), Géhu \& Biondi (1994) and Mucina \& al. (2016) the vegetation studied in this work is adscribed to the next syntaxa:

SAGinetea MARItimae Westhoff, Van Leeuwen \& Adriani 1962

Saginetalia maritimae Westhoff, Van Leeuwen \& Adriani 1962

Saginion maritimae Westhoff, Van Leeuwen \& Adriani 1962

Catapodio marini-Hymenolobetum revelierii ass. nova

Catapodio marini-Centaurietum tenuiflori ass. nova

CRithmo maritimi-Limonietea Braun-Blanq. in Braun-Blanq., Roussine \& Nègre 1952

Crithmo maritimi-Limonietalia Molinier 1934

Crithmo maritimi-Limonion articulati Paradis, Panaïotis, Piazza \& Pozzo di Borgo 2013

Loto cytisoidis-Juncetum acuti ass. nova

Asteriscion maritimi Géhu, Kaabeche \& Gharzouli 1992

Dauco hispanici-Asteriscetum maritimi Wojterski 1988

crithmetosum maritimi̇Géhu, Kaabèche \& Gharzouli 1992

ARtemisietea vUlgaris W. Lohmeyer, Preising \& Tüxen ex von Rochow 1951

Brachypodio ramosi-Dactyletalia hispanicae Biondi, Filigheddu \& Farris 2001

Reichardio maritimae-Dactylion hispanicae Biondi, Filigheddu \& Farris 2001

Loto cytisoidis-Dactylidetum hispanicae Biondi, Filigheddu \& Farris 2001

crithmetosum maritimi subass. nova

Helichryso italici-CRUCianelletea maritimae Géhu, Rivas-Mart. \& R. Tüxen in Bon et Géhu 1973) Sissingh 1974 em. Géhu \& Biondi 1994

Helichrysetalia italici Biondi \& Géhu 1994

Euphorbion pithuysae Biondi \& Géhu 1994

Helichryso italici-Thymelaeetum tartonrairae Bioret, Delbosc, Panaïotis \& Paradis ass. nova

typicum

schoenetosum nigricantis subass. nova

dianthetosum siculi subass. nova

\section{References}

Bardat, J., Bioret, F., Botineau, M., Boullet, V., Delpech, R., Géhu, J.M., Haury, J., Lacoste, A., Rameau, J.C., Roux, G., Royer, J.-M. \& Touffet, J. 2004. Prodrome des végétations de France. Mus. Nat. Hist. Nat., Paris. 171 pp.

Biondi, E., Filigheddu, R.S. \& Farris, E. 2001. Il Paesaggio vegetale della Nurra (Sardegna nord-occidentale) Pavia, Società italiana di fitosociologia. Fitosociologia 38(2), Suppl. 2: 3-105.

Brullo, S. \& Giusso del Galdo, G. 2003. La classe Saginetea maritimae in Italia Fitosociologia 2 40(2): 29-41.

De Foucault, B. \& Bioret, F. 2010. Contribution au Prodrome des végétations de France: classe des Saginetea maritimae Westhoff et al. 1952. J. Bot. Soc. Bot. France 50: 59-83.

Gamisans, J. \& Paradis, G. 1992. Flore et végétation de l'île Lavezzu. Trav. Sci. Parc Nat. Rég. Rés. Nat. Corse, France 37: 1-68.

Géhu, J.M. 1986. Des complexes de groupements végétaux à la phytosociologie paysagère contemporaine. Inf. Bot. Ital. 18 (1-2-3): 53-83.

Géhu, J.M. \& Biondi, E. 1994. Végétation du littoral de la Corse. Essai de synthèse phtytosociologique. Braun-Blanquetia 13: 3-149.

Géhu, J.M., Kaabeche, M. \& Gharzouli, R. 1992. Observations phytosociologiques sur le littoral Kabyle de Bejaia a Djijel Documents phytosociologiques, N.S., XIV: 305-322. 
Géhu, J.M. \& Rivas-Martínez, S. 1981. Notions fondamentales de Phytosociologie. In: Dierschke, H. (Ed.). Syntaxonomie. Ber. Int. Symp. Ver. Veg. 1977: 5-33. Ed. Cramer, Vaduz.

Guinochet, M. 1973. La phytosociologie. Collect. Ecol. I. Masson. Paris. 227 pp.

Jeanmonod, D. \& Gamisans, J. 2007. Flora Corsica. Édisud. 920 pp.

Khelifi, H., Bioret, F. \& Farsi, B. 2008. Apport à la connaissance syntaxonomique du littoral rocheux ouestalgérois. Acta Bot. Gall. 155(2): 163-177.

Mucina, L., Bültmann, H., Dierßen, K., Theurillat, J.-P., Raus, T., Čarni, A., Šumberová, K., Willner, W., Dengler, J., Gavilán, R.G., Chytrý, M., Hájek, M., Di Pietro, R., Iakushenko, D., Pallas, J., Daniëls, F.J.A., Bergmeier, E., Santos Guerra, A., Ermakov, N., Valachovič, M., Schaminée, J.H.J., Lysenko, T., Didukh, Y.P., Pignatti, S., Rodwell, Capelo, J., Weber, H.E., Solomeshch, A., Dimopoulos, P., Aguiar, C., Hennekens S.M. \& Tichý, L. 2016: Vegetation of Europe: Hierarchical floristic classification system of vascular plant, bryophyte, lichen, and algal communities. Appl. Veg. Sci. 19 (Suppl. 1): 3-264.

Paradis, G. 2010. Évaluation des habitats rocheux littoraux du thermoméditerranéen et du mésoméditerranéen inférieur de Corse. Off. Environ. Corse. Conserv. Bot. Corse, Corte. 306 pp.

Paradis, G., Lorenzoni, C., Piazza, C. \& Quilichini, M.C. 1999. Typologie d'habitats littoraux basée sur la phytosociologie: la végétation de pointes du sud-ouest de la Corse. Trav. Sci. Parc Nat. Rég. Rés. Nat. Corse 59: 23-90.

Paradis, G., Maurin, A. \& Piazza, C. 2010. Étude phytosociologique et cartographie de la végétation du site Natura 2000 Ricanto-Campo dell'Oro (Ajaccio, Corse). Bull. Soc. Bot. Centre-Ouest N.S. 41: 139-232.

Paradis, G, Panaïotis, C., Piazza, C. \& Pozzo di Borgo, M.L. 2013. Contributions à la connaissance des communautés aérohalines, principalement des Crithmo-Limonietea, du littoral rocheux de la Corse. Bull. Soc. Bot. Centre-Ouest N.S. 44: 515-576.

Paradis, G. \& Piazza, C. 1991. Contribution à l'étude de la végétation des dunes du site classé de l'Ostriconi (Corse). Bull. Soc. Bot. Centre-Ouest N.S. 22: 149-181.

Paradis, G, Panaïotis, C. \& Piazza, C. 2014. Contribution à la connaissance de la végétation thérophytique du littoral rocheux de la Corse (Saginetea maritimae, Tuberarietea guttatae, Sisymbrietea officinalis). Doc. Phytosoc. $2^{\mathrm{e}}$ N.S. 1: 352-391.

Paradis, G. \& Piazza, C. 2002. Contribution à l'étude de la flore et de la végétation des îlots satellites de la Corse. $9^{\mathrm{e}}$ note: îlot de Capense (Centuri, Cap Corse). Mond. Plant. 477: 1-6.

Rivas-Martinez, S., Diaz, T. E., Fernandez-Gonzalez, F., Izco, J., Loidi, J., Lousa, M. \& Penas, A. 2002. Vascular plants communities of Spain and Portugal. Addenda to the syntaxonomical cheklist of 2001, part II. Itinera Geobot. 15(1-2): 5-922.

Rivière, V., Damery, C., Delaugerre, M., Aboucaya, A., Faggio, G., Passetti, A., Pavon, D., Piazza, C. \& Ponel, P. 2012. $43^{\mathrm{ème}}$ parallèle de Bagaud à la Pointe du Cap Corse, mieux appréhender le fonctionnement des écosystèmes micro-insulaires et la place des espèces introduites et invasives. Ed. PIM. 31 pp.

Rossi, P. \& Rouire, J. 1980a. Carte géologique de la France au 1:250000. M. Ind. Bur. Rech. Géol. Min. Serv. Geol. Nat., Orléans.

Rossi, P. \& Rouire, J. 1980b. Notice explicative de la feuille Corse au 1:250000 M. Ind. Bur. Rech. Géol. Min. Serv. Geol. Nat., Orléans. 81pp.

Weber, H.E., Moravec, J. \& Theurillat, J.P. 2000. International Code of Phytosociological Nomenclature, 3rd edition. J. Veg. Sci. 11(5): 739-768.

Wojterski, T. 1985. Guide de l'excursion internationale de Phytosociologie, Algérie du Nord. Association Internationale pour l'Étude de la Végétation. Inst. Nat. Agron. El Harrach (Algérie). Impr. Goltze Druck, Göttingen. 274 pp. 